\title{
Tularemia, a re-emerging infectious disease in Iran and neighboring countries
}

\author{
Afsaneh Zargar ${ }^{1,2}$, Max Maurin ${ }^{3,4}$, Ehsan Mostafavi ${ }^{1,2}$ \\ ${ }^{1}$ Department of Epidemiology, Pasteur Institute of Iran, Tehran; ${ }^{2}$ Research Centre for Emerging and Reemerging Infectious Diseases, Pasteur \\ Institute of Iran, Akanlu, Kabudar-Ahang, Hamadan, Iran; ${ }^{3}$ Centre National de Référence des Francisella, Laboratoire de Bactériologie, \\ Département des Agents Infectieux, Institut de Biologie et Pathologie, Centre Hospitalier Universitaire de Grenoble, Université Joseph Fourier, \\ Grenoble; ${ }^{L}$ Laboratoire Adaptation et Pathogénie des Microorganismes, CNRS UMR 5163, Grenoble, France
}

\begin{abstract}
OBJECTIVES: Tularemia is a zoonotic disease transmitted by direct contact with infected animals and through arthropod bites, inhalation of contaminated aerosols, ingestion of contaminated meat or water, and skin contact with any infected material. It is widespread throughout the northern hemisphere, including Iran and its neighbors to the north, northeast, and northwest.

METHODS: In this paper, the epidemiology of tularemia as a re-emerging infectious disease in the world with a focus on Iran and the neighboring countries is reviewed.

RESULTS: In Iran, positive serological tests were first reported in 1973, in wildlife and domestic livestock in the northwestern and southeastern parts of the country. The first human case was reported in 1980 in the southwest of Iran, and recent studies conducted among at-risk populations in the western, southeastern, and southwestern parts of Iran revealed seroprevalences of 14.4, 6.52, and 6\%, respectively.

CONCLUSIONS: Several factors may explain the absence of reported tularemia cases in Iran since 1980. Tularemia may be underdiagnosed in Iran because Francisella tularensis subspecies holarctica is likely to be the major etiological agent and usually causes mild to moderately severe disease. Furthermore, tularemia is not a disease extensively studied in the medical educational system in Iran, and empirical therapy may be effective in many cases. Finally, it should be noted that laboratories capable of diagnosing tularemia have only been established in the last few years. Since both recent and older studies have consistently found tularemia antibodies in humans and animals, the surveillance of this disease should receive more attention. In particular, it would be worthwhile for clinical researchers to confirm tularemia cases more often by isolating F. tularensis from infected humans and animals.
\end{abstract}

KEY WORDS: Tularemia, Francisella tularensis, Bacterial infections, Rodentia

\section{INTRODUCTION}

Tularemia is a zoonotic disease caused by Francisella tularensis, a gram-negative, intracellular bacterium [1] transmitted thr-

Correspondence: Ehsan Mostafavi

Department of Epidemiology, Pasteur Institute of Iran, 69 Pasteur Ave., Tehran 1316943551, Iran

Tel/Fax: +98-21-66496448, E-mail: mostafavi@pasteur.ac.ir

Received: Jan 15, 2015, Accepted: Feb 22, 2015, Published: Feb 22, 2015

This article is available from: http://e-epih.org/

(C) 2015, Korean Society of Epidemiology

(C) This is an open-access article distributed under the terms of the Creative Commons Attribution License (http://creativecommons.org/licenses/by/3.0/), which permits unrestricted use, distribution, and reproduction in any medium, provided the original work is properly cited. ough direct contact with infected wildlife or domestic animals, arthropod bites (mostly ticks, but also flies and mosquitoes), inhalation of contaminated aerosols, ingestion of contaminated meat or water, and touching infected material. Direct humanto-human transmission has never been reported [2]. Tularemia has been isolated from 200 species of mammals, birds, reptiles, and fishes [2].

Laboratory workers, farmers, veterinarians, hunters, foresters, cooks, and butchers are at risk of tularemia infection [3]. F. tularensis is widespread in soil and water environments, where it can survive for up to 140 days [4]. However, no agreement exists about whether water can be considered a reservoir for this bacterium $[5,6]$. Since F. tularensis is highly virulent and can be spread via aerosols, causing severe pneumonia, it is a potential 
biological weapon [1].

The aim of this paper is to review the epidemiology of tularemia as a re-emerging infectious disease, with a focus on Iran and its neighboring countries.

\section{Clinical manifestations of tularemia}

The infectious dose of $F$. tularensis in humans is 25 bacteria for aerosol transmission and 100 bacteria for oral transmission $[7,8]$. After infection, the latent phase depends on the virulence and number of bacteria that entered the body, but most often lasts between three and six days [1]. The clinical manifestations of tularemia depend on the route through which the bacterium entered the body and are usually ulceroglandular or typhoidal, although oculoglandular, oropharyngeal, and pneumonic forms have also been reported [2]. The ulceroglandular form, which represents 75 to $85 \%$ of all tularemia cases, corresponds to a regional lymphadenopathy with a painful maculopapular lesion that evolves to an eschar at sites of skin infection; it can also occasionally develop into systemic disease with a 5 to $15 \%$ case fatality rate. The typhoidal form, which is an acute form that occurs in 5 to $15 \%$ of all cases of tularemia, is a febrile systemic disease that can include gastrointestinal and respiratory symptoms. It is associated with a case fatality rate of approximately $35 \%$. Early diagnosis of tularemia can help prevent fatal outcomes [9].

\section{Francisella tularensis subspecies}

F. tularensis currently includes four subspecies ([subsp.] tularensis, holarctica, mediasiatica, and novicida) with different phenotypic traits, virulence, and geographical distributions [7]. Only two subsp. (tularensis [type A] and holarctica [type B]) are causative agents of human tularemia.

Type A strains are highly virulent in humans. They are predominantly found in North America, where mice, rats, hares, and squirrels are natural reservoirs of these bacteria $[10,11]$. The case fatality rate of type A infections is 5 to $15 \%$ without antibiotic therapy (30 to $60 \%$ in cases involving severe pneumonia or septicemia), and $<2 \%$ with antibiotic therapy.Type A strains have been separated into genotypes (AI and AII) and subtypes (e.g., AIa and AIb). In the US, type AI predominates in the central and eastern parts of the country, whereas type AII predominates in the western part $[3,12]$. The subtype AIb is currently considered the most virulent.

Type B strains are usually associated with less severe forms of tularemia, with a case fatality rate $<1 \%$ in Europe and Asia. However, a $7 \%$ fatality rate was recently reported for type B infections in the US $[13,14]$. Tularemia is mostly transmitted through contact with contaminated dead or alive animals, arthropod bites (mainly ticks and mosquitoes), ingestion of contaminated water or food, and, rarely, inhalation of contaminat- ed aerosols. Mosquito bites are considered the main route of transmission in Russia and Scandinavia $[15,16]$. Mosquitoes can be infected with $F$. tularensis during their life as larvae in stagnant water, and then transmit the disease as adults [11].

F. tularensis subsp. novicida is not considered an etiological agent of tularemia. However, it has been occasionally associated with severe systemic disease in immunosuppressed patients [17]. It has been isolated from contaminated water, mainly in the US, and more rarely in Europe, Japan, China, and Australia $[1,17,18]$.

F. tularensis subsp. mediasiatica has only been isolated in Kazakhstan and Turkmenistan. Only a few studies have been conducted on this subsp. [19], but experiments in hares have shown that it is less virulent than subsp. holarctica (type B) [20].

\section{The geographic distribution of tularemia worldwide}

Tularemia is widespread in the northern hemisphere, mostly occurring in forests and mountainous regions [21]. The main endemic foci of the disease are Russia, Kazakhstan, Turkmenistan, Finland, and Sweden [22,23], and annual reports of tularemia incidence are published in the eastern European countries. Tularemia is considered a rare disease in western European countries, but recent outbreaks have occurred in Spain, involving hundreds of cases. The disease is also prevalent in Japan and in the northwest and northeast of China. Tularemia cases have been systematically reported in recent decades in Sweden, the US, and Canada (Figure 1) [24-27]. An outbreak of tularemia also occurred in South Korea in 1998 [28].

During an outbreak occurring in 1966 in Sweden, more than 600 tularemia cases were reported after the inhalation of contaminated aerosols on a farm [29]. In 2000 and 2003, following the war in Kosovo, outbreaks were seen in Kosovo in areas under the control of the United Nations, with 300 reported cases. The areas in question were not previously known as areas where tularemia was endemic [30].

Between 1997 and 2008, outbreaks were reported in America, Spain, Yugoslavia, Russia, Kosovo, Turkey, Switzerland, Ukraine, France, Canada, Bulgaria, Germany, Norway, Czech, Finland, Japan, and Slovakia [31].

\section{The status of tularemia in countries neighboring Iran}

In addition to the countries that were formerly part of the Soviet Union, tularemia has been reported in Asia in Turkey, China, Japan, and Iran [32].

Tularemia has been reported to the west of Iran (Turkey), as well as in countries bordering Iran to the north (Turkmenistan, Kazakhstan, and Azerbaijan) and to the east (Afghanistan).

Of the countries neighboring Iran, the greatest prevalence of tularemia has been reported in Turkey, where F. tularensis subsp. holarctica has been isolated [33]. Four major outbreaks were 


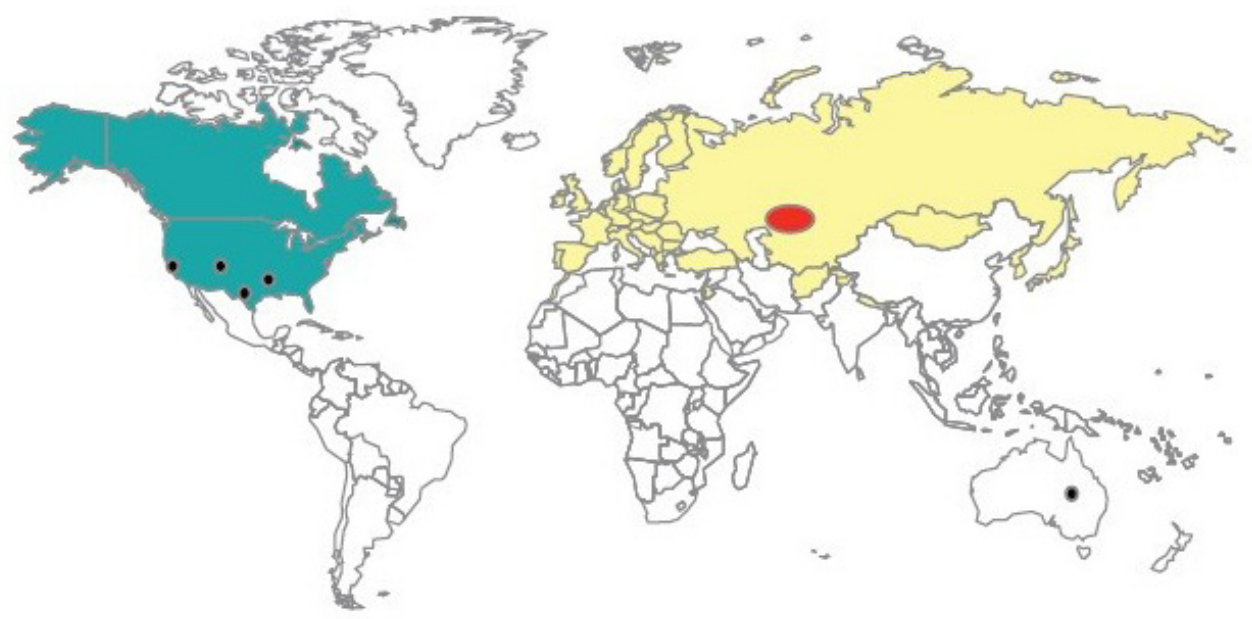

Figure 1. The global distribution of disease caused by Francisella tularensis subspecies. The different shadings represent the distributions of both type A and type B ( $\square$ ), type B ( $\square$ ) novicida ( $\square$ ), and mediasiatica ( $\square$ ). Source from Petersen JM, et al. Vet Res 2005;36:455-467 [23].

Table 1. Characteristics of tularemia outbreaks reported in Turkey

\begin{tabular}{|c|c|c|c|c|c|}
\hline Region & $\begin{array}{l}\text { Geographical location } \\
\text { in Turkey }\end{array}$ & Transmission & Clinical form & No. of cases & Year \\
\hline Kırklareli-Tekirdağ & Northwest & Water & Oropharyngeal & 133 & 1936 \\
\hline Bingöl-Tatvan-Reşadiye & East-Southeast-Northeast & Food & Oropharyngeal & 6 & 1937 \\
\hline Kırklareli-Lüleburgaz & Northwest & Water & Oropharyngeal & 15 & 1945 \\
\hline Antalya-Bademağacı & Southwest & Water & Oropharyngeal & 200 & 1953 \\
\hline Bursa & Northwest & Water & Oropharyngeal & 205 & 1988-1998 \\
\hline Ankara-Ayaş-Yağmurdede & Central & Water & Oropharyngeal & 16 & 1997 \\
\hline Düzce-Akçakoca & Northwest & Water & Ulceroglandular, oropharyngeal & 33 & 2000,2005 \\
\hline Bolu-Gerede-Yazıkara & Northwest & Water & Oropharyngeal & 21 & 2001 \\
\hline Amasya-Suluova & North & Unknown & Oropharyngeal, glandular & 86 & 2004 \\
\hline Zonguldak Kastamonu-Bartın & Northwest & Water & Oropharyngeal & 122 & $2004-2005$ \\
\hline Kars-Sarıkamış & East & Water & Oropharyngeal & 56 & 2004-2005 \\
\hline Kocaeli-Gölcük & Northwest & Water & Oropharyngeal & 145 & 2004-2005 \\
\hline Kocaeli-Karamürsel-Pazarköy & Northwest & Water & Oropharyngeal & 17 & 2005 \\
\hline Edirne-Lalapaşa-Demirköy & Northwest & Water & Oropharyngeal & 10 & 2005 \\
\hline Samsun-Havza & North & Water & Oropharyngeal, glandular & 75 & 2005-2007 \\
\hline Sakarya-Kocadöngel & Northwest & Water & Oropharyngeal & 63 & $2005-2006$ \\
\hline Bolu-Gerede-Nuhören & Northwest & Water & Unknown & 6 & 2006 \\
\hline Tokat & North & Water & Oropharyngeal, ulceroglandular & 23 & 2005,2010 \\
\hline Sivas & Central & Water & Oropharyngeal & 29 & $2008-2010$ \\
\hline Çanakkale & Northwest & Water & Oropharyngeal & 36 & 2009 \\
\hline Çankıır-Çerkeş-Kadıözü & Central & Water & Oropharyngeal & 18 & 2009 \\
\hline Tekirdağ-Hayrabolu-Muzruplu & Northwest & Water & Oropharyngeal & 8 & 2010 \\
\hline Konya & Central & Water & Oropharyngeal & 40 & $2009-2010$ \\
\hline Central Anatolia & Central & Water & $\begin{array}{l}\text { Oropharyngeal, glandular, } \\
\text { oculoglandular }\end{array}$ & 139 & 2009-2011 \\
\hline Total & & & & 1,441 & 1936-2011 \\
\hline
\end{tabular}

Source from Akalın H, et al. Int J Infect Dis 2009;13:547-551 [37]; Gürcan S. Balkan Med J 2014;31:3-10 [38].

reported between 1936 and 1953 in the western, southwestern, southeastern, and northwestern parts of Turkey [34]. After several years during which no cases were reported, tularemia was again reported in 1988 in multiple regions of Turkey [35,36].
Between 1988 and 2009, 1,300 cases of tularemia have been reported from various regions of Turkey [8,34].

Almost all cases of tularemia in Turkey have been oropharyngeal (Table 1); however, ulceroglandular and ocular forms of tu- 
laremia have also been diagnosed in Bursa, in the northwest of Turkey [34]. The main transmission route in Turkey is through drinking contaminated water. It has been hypothesized that water becomes contaminated by secretions from rodents and hares [39-41].The potential role of migrating birds in the transmission of the disease may be explained through the transfer of infected ticks or the direct contamination of water [42].

Although outbreaks have been reported in the northern and eastern regions of Turkey, most cases in Turkey have occurred in its northwestern and central regions. Both sexes and all age groups have been affected by the disease, and most cases have been reported in the autumn and winter [35,36].

Tularemia has been reported once in Afghanistan, in a porcupine in 1973 [43].Tick bites, rodents, sheep, and water transmission routes have been responsible for human tularemia cases in Armenia [44].

Tularemia has been carefully studied In Azerbaijan, where $F$. tularensis has been isolated from wild mammals, ticks, fleas, and water [45]. A study in Azerbaijan reported a tularemia seroprevalence of $15.5 \%$ [45].

In addition, $F$. tularensis subsp. mediasiatica has occasionally been isolated in central Asia (Turkmenistan and Kazakhstan) [46]. This subsp. is found in regions around the Amu Darya in Turkmenistan, and it is believed that it can be found in southern areas of central Asia as well $[32,45]$.

\section{The status of tularemia in Iran (Figure 2)}

In a national study conducted in 1973 in Iran, samples from more than 4,600 wild mammals and 200 sheep were collected from 47 regions. Attempts were made to isolate $F$. tularensis from the spleens of 3,548 animals, but no cultures were positive. Tularemia antibodies were found in eight sheep and three cows in the northwest of Iran, and in one porcupine in the southeast of Iran [44].

The first human case of tularemia (a glandular form) was reported in 1980 in Marivan, in the southwestern part of Kurdis$\tan$ Province. The case was a soldier stationed in that area for his military service, who suffered from symptoms including fatigue, myalgia, headache, anorexia, and inguinal lymphadenopathy [47].

In a study in Kurdistan Province, in the west of Iran, a study was carried out in 2011 and 2012 analyzing 100 patients who were referred to laboratories, 50 hunters and their families, 50 butchers and slaughterhouse workers, and 50 persons working in public healthcare centers in Sarvabad, Marivan, and Sanandaj. It was found that $42 \%$ of the subjects kept livestock. Tularemia antibodies were found in $14.4 \%$ of the 250 samples that were analyzed. The highest seroprevalence was found among hunters $(18 \%)$, whereas the lowest was observed among persons working in healthcare centers $(12 \%)$. The prevalence of tulare-

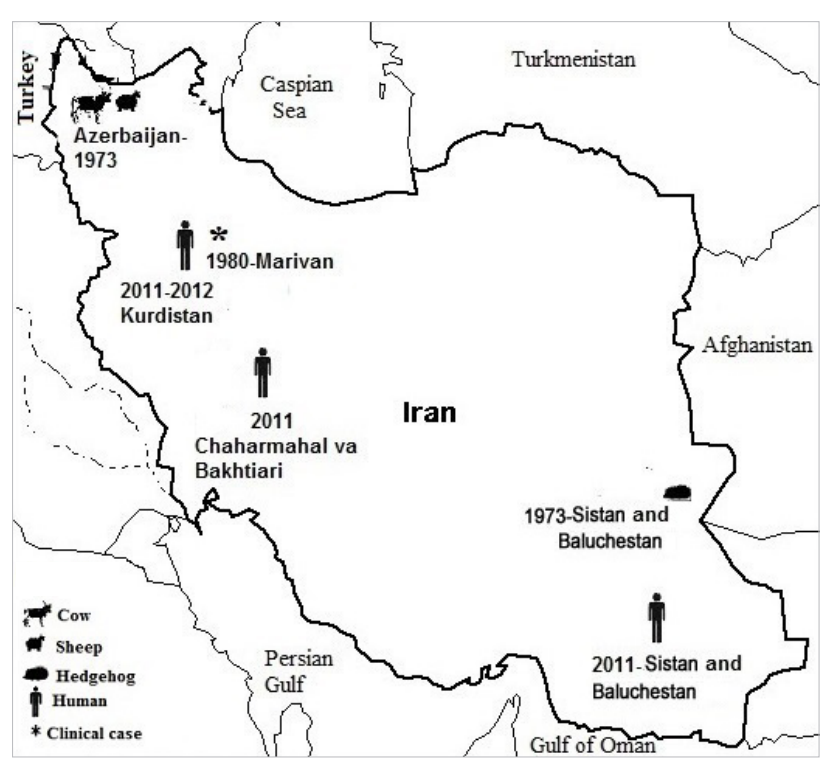

Figure 2. Distribution of clinical or serological positive cases of tularemia reported in different parts of Iran.

mia among people exposed to foxes (either hunters or persons consuming fox meat) was significantly higher than among people with no exposure to foxes (25 vs. $8.65 \%$ ) [48].

A study in 2011 that sampled 10 urban areas in Sistan and Baluchestan Province revealed tularemia seroprevalences of 5 and $9.38 \%$ among 184 butchers and slaughterhouse workers, respectively [49].

The same year, a study was conducted in Chaharmahal-Bakhtiari in 183 children between two and 18 years of age. This study revealed a seroprevalence of $6 \%$ for IgG antibodies against tularemia. However, none of the children presented clinical symptoms such as fever, ulcer, or lymphadenopathy. The subjects in this study lived in rural areas. Their parents worked as farmers or shepherds and they reported having close contact with animals such as dogs, cows, sheep, or other domestic animals [50].

\section{CONCLUSION}

According to studies recently conducted in Iran, the tularemia seroprevalence in at-risk populations has been found to be $14.4 \%$ [48], $6.52 \%$ [49], and $6 \%$ [50] in the west, southeast, and southwest of Iran, respectively. This may indicate that the tularemia seroprevalence is higher in Iran than in many other countries where tularemia is endemic; for instance, a tularemia seroprevalence of $2 \%$ was reported among hunters in Germany [51] and among trappers in Canada [52], a seroprevalence of 1 to $7 \%$ was reported among hunters and rural inhabitants in Turkey [53,54], and a seroprevalence of $9 \%$ was reported in 
landscapers in the US [55]. These findings are in sharp contrast with the fact that no tularemia cases have been reported in Iran since 1980.

No reservoir of $F$. tularensis has ever been precisely identified in Iran. However, in each country that has been studied, the prevalence of the disease strongly depends on the different traditions and customs of the inhabitants [56,57]. Multiple studies in Turkey have revealed that outbreaks in Turkey generally originate from water sources. Migrating birds may play an important role in outbreaks caused by water contamination, because birds may contaminate water with their feces [39,40]. A serological study in the west of Iran showed that the seroprevalence of tularemia was highest among local hunters (18\%). This study also showed a significant relationship between seroprevalence and eating meat from wild animals, such as foxes [48].

Type B tularemia is usually a benign disease [45,55], and $F$. tularensis subsp. holarctica is likely the etiological agent of tularemia in Iran, although no strain has yet been isolated in Iran. The clinical manifestations of tularemia in Iran are thus probably poorly specific and of low severity. Empirical therapies have probably been administrated in patients with suspected tularemia, especially because laboratories capable of diagnosing tularemia have only been established in the past few years. All these factors may explain the under-diagnosis of tularemia in Iran in recent decades [48].

Since annual reports of tularemia cases are published in countries that border Iran to the north, such as Turkey, more careful attention should be paid to the surveillance of tularemia in Iran, particularly in rural regions. Tularemia should receive a greater emphasis in the medical educational system of Iran. It is highly recommended that physicians and healthcare workers become more knowledgeable about the natural cycle of $F$. tularensis and the clinical manifestations of tularemia, in order to help them recognize the disease. Improvements in the Iranian healthcare system could lead to more reports of tularemia. Moreover, further studies are needed to better clarify the epidemiology of tularemia in Iran. The tularemia seroprevalence in other parts of Iran should be assessed, and the bacterium should be isolated from sources such as water, domestic livestock, and wild animals, in order to characterize the common subsp. and natural reservoirs of $F$. tularensis in Iran.

\section{ACKNOWLEDGEMENTS}

We gratefully acknowledge the financial support of the Pasteur Institute of Iran and the Center for Disease Control of the Iranian Ministry of Health and Medical Education (grant No. 582).

\section{CONFLICT OF INTEREST}

The authors have no conflicts of interest to declare for this study.

\section{REFERENCES}

1. SjÖStedt A. Tularemia: history, epidemiology, pathogen physiology, and clinical manifestations. Ann N Y Acad Sci 2007;1105:1-29.

2. World Health Organization. WHO guidelines on tularameia [cited 2015 Apr 6]. Available from: http://www.cdc.gov/tularemia/resources/whotularemiamanual.pdf.

3. Akimana C, Kwaik YA. Francisella-arthropod vector interaction and its role in patho-adaptation to infect mammals. Front Microbiol 2011; 2:34.

4. Mörner T, Mattsson R, Forsman M, Johansson KE, Sandström G. Identification and classification of different isolates of Francisella tularensis. Zentralbl Veterinarmed B 1993;40:613-620.

5. Hopla CE. The ecology of tularemia. Adv Vet Sic Comp Med 1974; 18:25-53.

6. Karlsson E, Svensson K, Lindgren P, Byström M, Sjödin A, Forsman $\mathrm{M}$, et al. The phylogeographic pattern of Francisella tularensis in Sweden indicates a Scandinavian origin of Eurosiberian tularaemia. Environ Microbiol 2013;15:634-645.

7. McLendon MK, Apicella MA, Allen LA. Francisella tularensis: taxonomy, genetics, and Immunopathogenesis of a potential agent of biowarfare. Annu Rev Microbiol 2006;60:167-185.

8. Saslaw S, Carlisle HN. Studies with tularemia vaccines in volunteers. IV. Brucella aggiutinins in vaccinated and nonvaccinated volunteers challenged with Pasteurella tularensis. Am J Med Sci 1961;242:166172.

9. State of New Jersey Department of Agriculture. Tularemia; 2003 [cited 2015 Apr 6]. Available from: http://www.state.nj.us/agriculture/divisions/ah/diseases/tularemia.html.

10. Goodman JS, Dennis DT, Sonenshine DE. Tick-borne diseases of humans. Washington, DC: ASM Press; 2005, p. 207-217.

11. Dennis DT, Inglesby TV, Henderson DA, Bartlett JG, Ascher MS, Eitzen E, et al. Tularemia as a biological weapon: medical and public health management. JAMA 2001;285:2763-2773.

12. Molins-Schneekloth CR, Belisle JT, Petersen JM. Genomic markers for differentiation of Francisella tularensis subsp. tularensis A.I and A.II strains. Appl Environ Microbiol 2008;74:336-341.

13. Pechous RD, McCarthy TR, Zahrt TC. Working toward the future: insights into Francisella tularensis pathogenesis and vaccine development. Microbiol Mol Biol Rev 2009;73:684-711.

14. Nigrovic LE, Wingerter SL. Tularemia. Infect Dis Clin North Am 2008;22:489-504.

15. Eliasson H, Bäck E. Tularaemia in an emergent area in Sweden: an analysis of 234 cases in five years. Scand J Infect Dis 2007;39:880889.

16. Eliasson H, Lindbäck J, Nuorti JP, Arneborn M, Giesecke J, Tegnell A. The 2000 tularemia outbreak: a case-control study of risk factors in disease-endemic and emergent areas, Sweden Emerg Infect Dis 2002;8:956-960.

17. Hollis DG, Weaver RE, Steigerwalt AG, Wenger JD, Moss CW, Brenner DJ. Francisella philomiragia comb. nov. (formerly Yersinia philomiragia) and Francisella tularensis biogroup novicida (formerly Francisella novicida) associated with human disease. J Clin Micrbiol 1989; 
27:1601-1608.

18. Whipp MJ, Davis JM, Lum G, de Boer J, Zhou Y, Bearden SW, et al. Characterization of a novicida-like subspecies of Francisella tularensis isolated in Australia. J Med Microbiol 2003;52:839-842.

19. Taleski, V, Zdravkovska M, Markovski V. Francisella tularensis-potential biological agent. Tirana: The 5th Eurasia Congress of Infectious Diseases; 2013, p. 444-445.

20. Champion MD, Zeng Q, Nix EB, Nano FE, Keim P, Kodira CD, et al. Comparative genomic characterization of Francisella tularensis strains belonging to low and high virulence subspecies. PLoS Pathog 2009;5:e1000459.

21. May JM. Studies in disease ecology. New York: Hafner; 1961, p. 387433.

22. Tärnvik A, Priebe HS, Grunow R. Tularaemia in Europe: an epidemiological overview. Scand J Infect Dis 2004;36:350-355.

23. Petersen JM, Schriefer ME. Tularemia: emergence/re-emergence. Vet Res 2005;36:455-467.

24. Berdal BP, Mehl R, Meidell NK, Lorentzen-Styr AM, Scheel O. Field investigations of tularemia in Norway. FEMS Immunol Med Microbiol 1996;13:191-195.

25. Ohara Y, Sato T, Fujita H, Ueno T, Homma M. Clinical manifestations of tularemia in Japan--analysis of 1,355 cases observed between 1924 and 1987. Infection 1991;19:14-17.

26. Tärnvik A, Sandström G, Sjöstedt A. Epidemiological analysis of tularemia in Sweden 1931-1993. FEMS Immunol Med Microbiol 1996; 13:201-204.

27. Farlow J, Wagner DM, Dukerich M, Stanley M, Chu M, Kubota K, et al. Francisella tularensis in the United States. Emerg Infect Dis 2005; 11:1835-1841.

28. Lim HS, Cheong HK, Ahn WS, Kim MY, Kim DH. A case of ulceroglandular tularemia occurred in Korea. Korean J Epidemiol 1998;20: 32-38 (Korean).

29. Dahlstrand S, Ringertz O, Zetterberg B. Airborne tularemia in Sweden. Scand J Infect Dis 1971;3:7-16.

30. Reintjes R, Dedushaj I, Gjini A, Jorgensen TR, Cotter B, Lieftucht A, et al. Tularemia outbreak investigation in Kosovo: case control and environmental studies. Emerg Infect Dis 2002;8:69-73.

31. Salman MD, Tarrés-Call J, Estrada-Peña A. Ticks and tick-borne diseases: geographical distribution and control strategies in the Euro-Asia region. Wallingford: CABI; 2013, p. 79.

32. Arata A, Chamsa H, Farhang-Azad A, Mescerjakova O, Neronov V, Saidi S. First detection of tularaemia in domestic and wild mammals in Iran. Bull World Health Organ 1973;49:597-603.

33. Gurcan S, Karabay O, Karadenizli A, Karagol C, Kantardjiev T, Ivanov IN. Characteristics of the Turkish isolates of Francisella tularensis. Jpn J Infect Dis 2008;61:223-225.

34. Akalin H, Helvaci S, Gedikoğlu S. Re-emergence of tularemia in Turkey. Int J Infect Dis 2009;13:547-551.

35. Helvaci S, Gedikoğlu S, Akalin H, Oral HB. Tularemia in Bursa, Turkey: 205 cases in ten years. Eur J Epidemiol 2000;16:271-276.

36. Gürcan S, Otkun MT, Otkun M, Arikan OK, Ozer B. An outbreak of tularemia in Western Black Sea region of Turkey. Yonsei Med J 2004; 45:17-22.

37. Akalın H, Helvacı S, Gedikoğlu S. Re-emergence of tularemia in Turkey. Int J Infect Dis 2009;13:547-551.

38. Gürcan S. Epidemiology of tularemia. Balkan Med J 2014;31:3-10.
39. Gürcan S, Eskiocak M, Varol G, Uzun C, Tatman-Otkun M, Sakru N, et al. Tularemia re-emerging in European part of Turkey after 60 years. Jpn J Infect Dis 2006;59:391-393.

40. Leblebicioglu H, Esen S, Turan D, Tanyeri Y, Karadenizli A, Ziyagil F, et al. Outbreak of tularemia: a case-control study and environmental investigation in Turkey. Int J Infect Dis 2008;12:265-269.

41. Ozdemir D, Sencan I, Annakkaya AN, Karadenizli A, Guclu E, Sert E, et al. Comparison of the 2000 and 2005 outbreaks of tularemia in the Duzce region of Turkey. Jpn J Infect Dis 2007;60:51-52.

42. Hubálek Z. An annotated checklist of pathogenic microorganisms associated with migratory birds. J Wildl Dis 2004;40:639-659.

43. Farhang-Azad A, Mescerjakova I, Neronov V. Afghan hedgehog, a new reservoir of tularemia. Bull Soc Pathol Exot Filiales 1973;66:266269.

44. Arata A, Chamsa H, Farhang-Azad A, Mescerjakova O, Neronov V, Saidi S. First detection of tularemia in domestic and wild mamals in Iran. Bull World Health Organ 1973;49:597-603.

45. Clark DV, Ismailov A, Seyidova E, Hajiyeva A, Bakhishova S, Hajiyev $\mathrm{H}$, et al. Seroprevalence of tularemia in rural Azerbaijan. Vector Borne Zoonotic Dis 2012;12:558-563.

46. Motarjemi Y, Moy G, Todd E. Encyclopedia of food safety. Amsterdam: Academic Press; 2014, p. 442-444.

47. Karimi Y, Salarkia F, Ghasemi MA. Tularemia: first human case in Iran. J Med Coun Iran 1981;8:134-141.

48. Esmaeili S, Gooya MM, Shirzadi MR, Esfandiari B, Amiri FB, Behzadi MY, et al. Seroepidemiological survey of tularemia among different groups in western Iran. Int J Infect Dis 2014;18:27-31.

49. Esmaeili S, Esfandiari B, Maurin M, Gouya MM, Shirzadi MR, Amiri FB, et al. Serological survey of tularemia among butchers and slaughterhouse workers in Iran. Trans R Soc Trop Med Hyg 2014;108: 516-518.

50. Khoshdel A, Saedi Dezaki E, Ganji F, Habibian R, Imani R, Taheri E, et al. First seroprevalence survey of children with tularemia infection in Chaharmahal va Bakhtiari province, Iran. Iran J Pathol 2014;9:2327.

51. Jenzora A, Jansen A, Ranisch H, Lierz M, Wichmann O, Grunow R. Seroprevalence study of Francisella tularensis among hunters in Germany. FEMS Immunol Med Microbiol 2008;53:183-189.

52. Lévesque B, De Serres G, Higgins R, D’Halewyn MA, Artsob H, Grondin J, et al. Seroepidemiologic study of three zoonoses (leptospirosis, Q fever, and tularemia) among trappers in Québec, Canada. Clin Diagn Lab Immunol 1995;2:496-498.

53. Yeşilyurt M, Kılıç S, Celebi B, Gül S. Tularemia: are hunters really a risk group?. Mikrobiyol Bul 2012;46:153-155 (Turkish).

54. Yazgı H, Uyanık MH, Ertek M, Kılıç S, Kireçci E, Ozden K, et al. Tularemia seroprevalence in the risky population living in both rural and urban areas of Erzurum. Mikrobiyol Bul 2011;45:67-74 (Turkish).

55. Feldman KA, Stiles-Enos D, Julian K, Matyas BT, Telford SR 3rd, Chu MC, et al. Tularemia on Martha's Vineyard: seroprevalence and occupational risk. Emerg Infect Dis 2003;9:350-354.

56. Anda P, Segura del Pozo J, Díaz García JM, Escudero R, García Peña FJ, López Velasco MC, et al. Waterborne outbreak of tularaemia associated with crayfish fishing. Emerg Infect Dis 2001;7:575-582.

57. Helvaci S, Gedikoğlu S, Akalin H, Oral HB. Tularemia in Bursa, Turkey:205 cases in 10 years. Eur J Epidemiol 2000;16:271-276. 